\title{
KLASIFIKASI MUTU TELUR BURUNG PUYUH BERDASARKAN WARNA DAN TEKSTUR MENGGUNAKAN METODE K-NEAREST NEIGHBOR (KNN) DAN FUSI INFORMASI
}

\author{
Arwin Datumaya Wahyudi Sumari*', Putri Indah Mawarni ${ }^{2}$, Arie Rachmad Syulistyo ${ }^{3}$ \\ ${ }^{1,2,3}$ Politeknik Negeri Malang, ${ }^{1}$ Universitas Pertahanan Bogor \\ ${ }^{1}$ arwin.sumari@polinema.ac.id, ${ }^{2}$ putri.pi1188@gmail.com, ${ }^{3}$ arie.rachmad.s@polinema.ac.id \\ *Penulis Korespondensi
}

(Naskah masuk: 23 November 2020, diterima untuk diterbitkan: 19 Oktober 2021)

\begin{abstract}
Abstrak
Kualitas produk merupakan faktor utama untuk menjamin keberlangsungan satu usaha peternakan. Perusahaan telur puyuh yang memiliki ribuan burung Puyuh seperti CV. NS Quail Farm mampu memproduksi ribuan telur dalam sehari karena seekor burung Puyuh mampu menghasilkan 250-300 butir telur per tahun. Penyeleksian ribuan telur-telur tersebut dilakukan secara tradisional oleh para pekerja peternakan sehingga kualitas telur-telur hasil seleksi bergantung pada perspektif masing-masing pekerja. Guna memperoleh telur hasil seleksi dengan kualitas yang sama, maka dibangun sebuah sistem pencitraan digital untuk pemilihan telur burung Puyuh berdasarkan fitur warna dan tekstur kulit telur menggunakan metode klasifikasi K-Nearest Neighbor (KNN) yang dikombinasikan dengan fusi informasi. 300 data citra telur burung Puyuh diolah menggunakan normalisasi Red, Green, Blue (RGB) dan Otsu thresholding guna memperoleh fitur warna dan fitur tekstur yang kemudian difusikan menjadi fitur terfusi tunggal sebagai masukan pengklasifikasi KNN. Dari hasil-hasil penelitian, disimpulkan bahwa sistem berhasil mengklasifikasikan mutu telur Baik, Sedang, dan Buruk dengan akurasi ratarata sebesar 77,78\%. Disamping itu, klasifikasi dengan fusi informasi mampu mengungguli klasifikasi tanpa fusi informasi sebesar $11,11 \%$ pada nilai $K$ yang sama yakni 7 dan fusi informasi juga mampu mempercepat proses klasifikasi sebesar 0,22 detik dibandingkan terhadap klasifikasi tanpa fusi informasi.
\end{abstract}

Kata kunci: Fusi Informasi, Klasifikasi, K-Nearest Neighbor, Sistem Pencitraan Digital, Telur Burung Puyuh

\section{CLASSIFICATION OF THE QUALITY QUAIL EGGS BASED ON COLOR AND TEXTURE USING K-NEAREST NEIGHBOR (KNN) METHOD AND INFORMATION FUSION}

\begin{abstract}
The quality of product us a primary factor to ensure the sustainability of a farm business. A company which has thousands of quail such as CV. NS Quail is capable of producing thousand quail eggs in a day because a quail is able to produce 250-300 eggs per year. The selection of the eggs is carried out traditionally by the farm workers so that the quality of the selected eggs are depended on the perspective of each worker. In order to obtain the same quality of the selected eggs, a digital imaging system for quail egg selection based on color feature and texture feature using K-Nearest Neighbor $(K N N)$ combined with information fusion is developed. 300 image data of quail egg was processed using Red, Green, Blue (RGB) and Otsu thresholding to obtain color feature and texture feature which then were fused to become single fused feature as the input to KNN classifier. From the research results, it is concluded that the system was managed to classify egg quality as good, medium, and bad with an accuracy of $77,78 \%$. In addition, the classification with information fusion was able to outperform the classification without information fusion by $11.11 \%$ at the same $K$ value of 7 and information fusion is also able to accelerate classification process by 0.22 seconds compared to that of without information fusion.
\end{abstract}

Keywords: Classification, Digital Imaging System, Information Fusion, K-Nearest Neighbor, Quail Eggs

\section{PENDAHULUAN}

Salah satu dari sekian banyak burung yang masih dapat ditemukan di pedesaan atau di hutan adalah burung Puyuh. Pada umumnya, jenis burung ini dapat ditemukan di padang rumput terbuka, sawah yang baru dipanen atau di semak-semak. Banyak orang beternak burung Puyuh karena selain 
dapat dijadikan sebagai mata pencaharian, ia tidak membutuhkan lahan yang luas. Dengan luas lahan sekitar 15-20 $\mathrm{m}^{2}$ peternak dapat memelihara setidaknya 1.000 ekor burung Puyuh (Saparinto \& Marsudi, 2012).

Salah satu perusahaan yang mengelola peternakan dengan ribuan burung Puyuh jenis Blaster adalah NS Quail Farm. Produktivitas burung Puyuh cukup tinggi dalam setahun dimana satu burung Puyuh dapat menghasilkan 250-300 butir telur. Seekor burung Puyuh dapat menghasilkan setidaknya satu butir telur perhari (Wuryadi, 2013). Dengan jumlah burung yang jumlahnya ribuan, panen telur dapat dilakukan setiap hari baik pada waktu pagi maupun sore hari. Telur-telur yang sudah diambil kemudian diseleksi, dengan cara memisahkan telur dengan kualitas yang baik dari yang jelek (Saparinto \& Marsudi, 2012).

Pada umumnya telur burung Puyuh berwarna putih dan memiliki bintik-bintik berwarna hitam pada cangkang telurnya dimana kualitasnya dapat dilihat berdasarkan pola tekstur dan warna pada kulit telurnya. Pemilihan telur yang tepat dapat meningkatkan kualitas produksi telur burung Puyuh dan sangat berpengaruh pada harga jualnya. Pada umumnya penilaian kualitas telur burung Puyuh dilakukan secara tradisional yakni dari perspektif para pekerja peternakan, dan penilaian ini subyektif dari para pekerja masing-masing sehingga terjadi perbedaan kualitas.

Dari permasalahan tersebut diperlukan sebuah sistem pencitraan digital sebagai pendukung mata manusia untuk membantu dalam mengklasifikasikan telur burung Puyuh yang bermutu. Salah satu metode yang banyak digunakan untuk melakukan klasifikasi adalah K-Nearest Neighbor (KNN) diantaranya untuk mendeteksi telur ayam dengan pengolahan citra histogram equalization dengan analisa tekstur ciri orde pertama (Rahmadianto, Mulyanto, \& Sutojo, 2019). KNN juga telah digunakan untuk klasifikasi jenis batuan beku melalui citra berwarna dengan menggunakan metode Local Binary Pattern (LBP) (Sultoni, Hidayat, \& Subandrio, 2019) dan juga untuk klasifikasi motif batik pesisir dengan metode pengolahan citra Otsu thresholding (Ningrum, Hendriyanto, \& Kurniawan, 2017. Penelitian (Abadi dkk, 2018) menggunakan Sistem Pakar untuk menentukan telur burung puyuh terbaik berdasarkan pada ukuran, tekstur, warna, ketebalan cangkang, ukuran, dan kebersihan telur. Namun pada penelitian ini tidak menggunakan pengolahan citra digital sebagai salah satu metodenya.

Dalam penelitian dibangun sebuah sistem pencitraan digital untuk melakukan klasifikasi pada telur burung puyuh sebagai dasar pemilihan telur yang bermutu. Klasifikasi didasarkan pada tekstur dan warna telur burung Puyuh menggunakan pengklasifikasi KNN yang dikombinasikan dengan fusi informasi guna memperoleh hasil klasifikasi yang lebih baik dan lebih cepat. Sistem yang dibuat ini dapat menampilkan tiga kelas mutu telur burung Puyuh yakni kelas telur mutu Baik, mutu Sedang dan mutu Buruk. Penetapan mutu telur burung Puyuh ini didasarkan pada kuantitas noktah hitam pada cangkang setiap telur.

\section{METODE PENELITIAN}

\subsection{Data Penelitian}

Data yang menjadi objek penelitian adalah citra telur burung Puyuh, yang terdiri atas 300 butir telur dengan rincian 100 butir telur bermutu Baik, 100 butir telur bermutu Sedang, dan 100 butir telur bermutu Buruk. Data pelatihan sebanyak 270 buah dengan rincian 90 butir telur masing-masing bermutu Baik, Sedang, dan Buruk, sedangkan data uji menggunakan 30 butir telur masing-masing 10 butir telur bermutu Baik, Sedang, dan Buruk. Pada Gambar 1 diperlihatkan 3 contoh telur burung Puyuh yang belum diproses melalui pengolahan citra digital guna diekstraksi fitur-fiturnya yakni fitur warna dan fitur tekstur. Gambar 1(a) adalah contoh telur burung Puyuh yang memiliki mutu bBaik, Gambar 1(b) adalah contoh telur burung Puyuh dengan mutu Sedang, dan Gambar 1(c) adalah contoh telur burung Puyuh yang memiliki mutu Buruk.

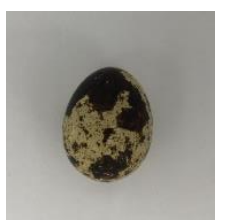

(a)

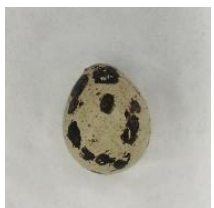

(b)

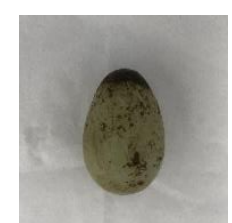

(c)
Gambar 1. Contoh data telur burung Puyuh dengan mutu (a) Baik, (b) Sedang, dan (c) Buruk.

\subsection{Metode Pengambilan Data}

Data primer diperoleh dari hasil wawancara dengan pemilik NS Quail Farm dan observasi langsung ke peternakannya. Data-data yang diperoleh yakni ciri telur burung Puyuh berdasarkan tekstur dan warna sebagai landasan untuk mengklasifikasikan mutu telur ke dalam tiga kelas yaitu mutu telur burung Puyuh Baik, Sedang, dan Buruk. Klasifikasi terkait mutu telur burung Puyuh tersebut didasarkan pada hasil observasi para pekerja NS Quail Farm, dan data-data klasifikasi manusia ini dijadikan dasar bagi sistem pengklasifikasi mutu telur burung Puyuh menggunakan teknologi

Agar data yang diperoleh konsisten, pengambilan citra telur burung Puyuh menggunakan kardus yang telah dirancangan sedemikian rupa dan diberi latar belakang putih. Pengambilan data citra menggunakan kamera iPhone $\mathrm{X}$ dengan jarak antara objek dan kamera yakni $15 \mathrm{~cm}$, dan dilakukan perbesaran sebanyak dua kali pada objek. Salah satu teknik untuk mereduksi kemungkinan terjadinya bias dari citra yang diperoleh melalui proses akusisi data ini, digunakan teknik Otsu thresholding dengan 
mengatur titik ambangnya semaksimal mungkin untuk memperoleh fitur yang terbaik.

\subsection{Metode Pengolahan Data}

Pengolahan data citra diilustrasikan secara sederhana pada Gambar 2. Citra telur burung puyuh setelah dimasukkan akan dilakukan pengolahan awal yang diawali dari memperkecil dimensi citra dan selanjutnya diambil nilai RGB-nya. Ekstraksi fitur warna dilakukan dengan normalisasi RGB dan disimpan nilainya. Citra tersebut kemudian diubah menjadi citra gray scale untuk diproses oleh metode Otsu untuk memperoleh fitur tekstur.

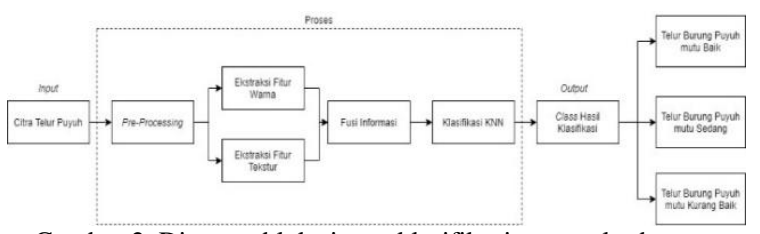

Gambar 2. Diagram blok sistem klasifikasi mutu telur burung Puyuh.

Setelah dilakukan kedua macam fitur diekstraksi, proses berikutnya adalah fusi informasi guna memperoleh fitur terfusi sebagai masukan KNN untuk proses klasifikasi. Hasil dari proses klasifikasi adalah kelas klasifikasi telur burung Puyuh. Diagram alir sistem klasifikasi yang menjadi landasan pengimplementasiannya ke bentuk sebuah aplikasi perangkat lunak dapat dilihat pada Gambar 3.

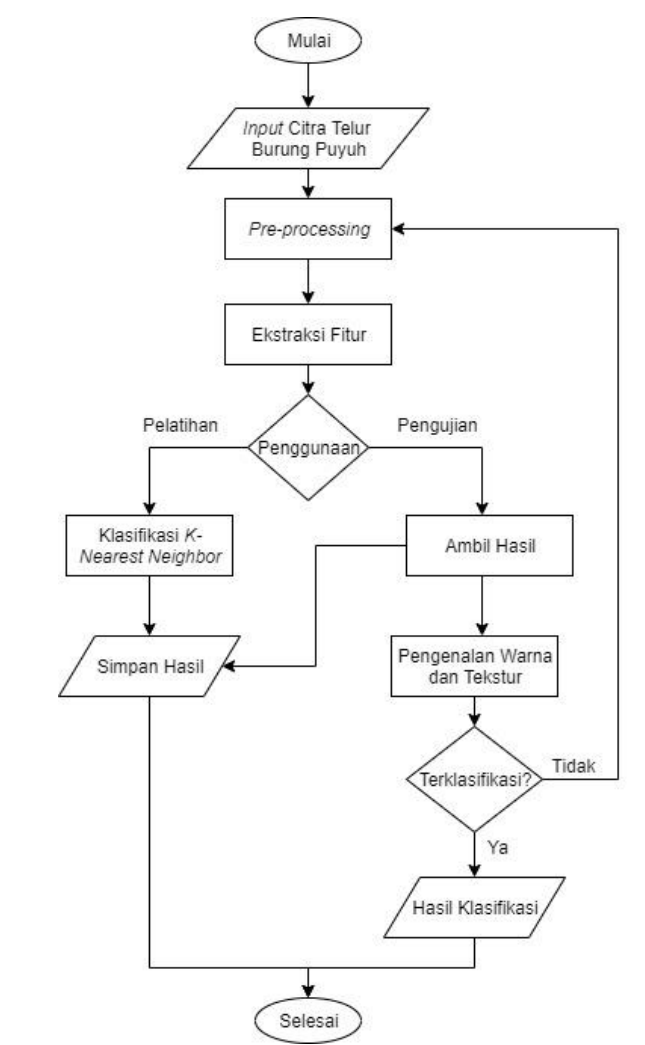

Gambar 3. Diagram alir sistem klasifikasi mutu telur burung Puyuh.

\subsection{Metode Pengujian Sistem}

Ada berbagai macam metode akurasi yang dapat diimplementasikan untuk mengetahui tingkat kecocokan terhadap proses klasifikasi, salah satunya metode confusion matrix (Rahmadianto, Mulyanto, $\&$ Sutojo, 2019). Tabel confusion matrix dapat dilihat pada Tabel 1. Nilai akurasi klasifikasi didapatkan dengan menggunakan Persamaan (13) (Han, Kamber, \& Pei, 2012). Confusion matrix akurasi dipilih untuk melihat performa uji terhadap nilai $K$ yang dipilih diman semakin besar nilai akurasi maka semakin tepat nilai $K$ yang dipilih.

Tabel 1. Model Confusion Matrix

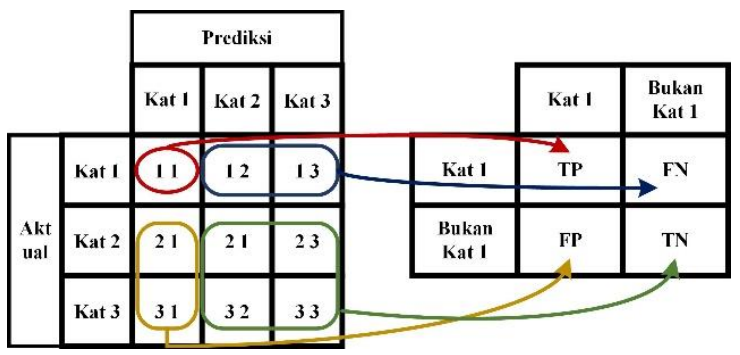

Dari Tabel 1 dapat dijelaskan sebagai berikut:

- True Positive (TP) adalah data benar yang diprediksi benar bahwa data tersebut benar.

- True Negative (TN) adalah data salah yang diprediksi benar bahwa data tersebut salah.

- False Positive (FP) adalah data diprediksi benar namun seharusnya salah.

- False Negative (FN) adalah data diprediksi salah namun seharusnya benar.

Akurasi $=\frac{T P+T N}{T P+T N+F P+F N} \times 100 \%$

\section{LANDASAN TEORI}

Sistem pencitraan untuk klasifikasi telur burung Puyuh yang dirancang dan diimplementasikan menggunakan metode pengolahan citra untuk memperoleh fitur warna dan fitur tekstur yakni normalisasi Red, Green, Blue (RGB) dan Otsu thresholding. Sebelum diklasifikasikan oleh pengklasifikasi KNN, kedua fitur akan difusikan untuk memperoleh fitur terfusi tunggal melalui fusi informasi. Kekuatan dari sistem pengklasifikasi ini adalah pada fusi informasi dan merupakan fitur sistem yang membedakannya dengan sistem-sistem sejenis.

\subsection{Pengolahan Citra}

Citra digital (raster image) merupakan representasi numerik dalam bentuk nilai biner 8 bit dari citra dua dimensi (2D) yang disebut dengan piksel dengan jumlah baris dan kolom yang tetap. Piksel yang merupakan terjemahan dari pixel (picture element) adalah elemen gambar terkecil dari citra digital dan disimpan pada memori komputer 
sebagai map raster, yaitu larik (array) dua dimensi bertipe integer (Widyardini, 2018). Citra merupakan gambar 3-dimensi (3D) dari suatu fungsi warna sebagai fungsi ruang (spatial) $x$ dan $y$. Dari sisi komputer, warna dapat dinyatakan sebagai angka dalam bentuk skala RGB. Karena citra adalah rangkaian angka-angka, maka citra dapat diproses secara digital (Widyardini, 2015).

\subsection{Normalisasi RGB}

Model RGB merupakan model yang banyak digunakan untuk merepresentasikan citra kedalam tiga komponen warna merah, hijau, dan biru. Selain itu terdapat juga model normalisasi RGB dimana model ini terdapat tiga komponen yaitu, $r, g, b$ yang merepresentasikan presentase dari sebuah piksel pada citra digital. Perhitungan normalisasi RGB dilakukan menggunakan Persamaan (1) hingga Persamaan (3) (Kusmanto \& Tompunu, 2011).

$r=\frac{R}{255}$

$g=\frac{G}{255}$

$b=\frac{B}{255}$

\subsection{Otsu Thresholding}

Thresholding atau penitik-ambangan secara umum didefinisikan sebagai pemberian ambang batas pada sekumpulan data yang akan memisahkan kumpulan tersebut pada dua sisi yang berbeda. Sebagai contoh adalah pembineran (binarization) sekumpulan data dalam himpunan $A=\{1,2, \ldots, 9\}$ dengan aturan bila $A \geq 4$ maka $A_{\text {bin }}=1$, sebaliknya $A_{\text {bin }}=0 . \quad$ Setelah thresholding diterapkan, akan diperoleh himpunan $A_{\text {bin }}=$ $\{0,0,0,1,1,1,1,1,1$,$\} . Thresholding merupakan salah$ satu metode segmentasi yang banyak digunakan dalam ekstraksi fitur pada pengolahan awal data citra. Pembineran telah membuat segmentasi atau pemisahan antara data dibawah titik ambang dan data diatas titik ambang.

Salah satu teknik yang banyak digunakan adalah otsu thresholding yang diklaim sebagai metode pemilihan titik ambang yang paling sederhana (Otsu, 1979). Metode Otsu mengubah citra digital warna abu-abu menjadi hitam putih berdasarkan perbandingan nilai ambang dengan nilai warna piksel citra digital. Langkah awal yang harus dilakukan adalah membuat histogram guna diketahui jumlah piksel untuk setiap tingkat keabuan dinyatakan dengan i sampai dengan L. Level ke-i dimulai dari 1, yaitu piksel 0 . Untuk L, maksimal level adalah 256 dengan piksel bernilai 255 (Syafi'I, Wahyuningrum \& Muntasa, 2015).
Formula-formula metode Otsu mencakup komputasi untuk memperoleh nilai probabilitas menggunakan Persamaan (4), nilai rerata intensitas global dengan Persamaan (5), nilai probabilitas kemunculan kelas latar belakang beserta reratanya dengan Persamaan (6) dan Persamaan (7). Komputasi untuk nilai probabilitas kemunculan kelas latar depan (foreground) beserta reratanya dengan Persamaan (8) dan Persamaan (9), sedangkan untuk memperoleh nilai varian antar kelas menggunakan Persamaan (10).

$$
\begin{aligned}
& P_{i}=\frac{n_{i}}{N} \\
& \mu T=\sum_{i=1}^{L} i \cdot p_{i} \\
& \omega_{0}=\sum_{i=1}^{k} p_{i} \\
& \mu_{0}=\sum_{i=1}^{k} \frac{i \cdot p_{i}}{\omega_{0}} \\
& \omega_{1}=\sum_{i=k+1}^{L} p_{i} \\
& \mu_{1}=\sum_{i=k+1}^{L} \frac{i \cdot p_{i}}{\omega_{1}} \\
& \sigma_{\beta}^{2}=\omega_{0}\left(\mu_{0}-\mu_{T}\right)^{2}+\omega_{1}\left(\mu_{1}-\mu_{T}\right)^{2}
\end{aligned}
$$

\subsection{Fusi Informasi}

Fusi informasi adalah suatu metode yang digunakan untuk menggabungkan beberapa fitur menjadi satu fitur yang mewakili fitur-fitur tersebut. Penggabungan informasi berasal dari pengamatan bagaimana manusia dapat membuat sebuah keputusan atau tindakan secara akurat dan cara cepat setelah memiliki banyak informasi mengenai satu situasi tertentu. Metode ini muncul terinspirasi dari bagaimana cara kerja otak manusia, yakni otak manusia menerima banyak informasi yang kemudian informasi-informasi tersebut difusikan guna memperoleh pengetahuan sebagai landasan untuk pengambilan keputusan (Sumari \& Ahmad, 2016).

Fusi informasi pada dasarnya ekstraksi pengetahuan dari sekumpulan data (Sumari \& Ahmad, 2017). Terdapat beragam metode untuk fusi informasi dan juga tatarannya, terdiri atas mode Data-Fitur-Objek-Relasi yang dipetakan dalam bentuk tabel yang bersesuaian (Sumari \& Ahmad, 2008). Dalam penelitian ini dipilih mode Feature InFeature Out (FEI-FEO) yakni masukan berupa dua fitur berbeda dan keluaran berupa sebuah fitur terfusi sebagaimana diperlihatkan pada Persamaan (11). Fusi fitur pada pengolahan citra digital juga digunakan oleh (Su \& Chen, 2013) menggunakan pengklasifikasi Support Vector Machine (SVM). 
Fitur_terfusi $=$ Fitur $(i) \oplus$ Fitur $(i+1)$

Bila $\operatorname{Fitur}(i)=$ warna $\quad$ dan $\operatorname{Fitur}(i+1)=$ tekstur, maka:

$$
\text { Fitur_terfusi }=\text { Fitur }(\text { warna }) \oplus \text { Fitur }(\text { tekstur })
$$

Dengan $\oplus$ adalah operator fusi informasi berupa operator digital sederhana seperti $A N D$ atau $X O R$.

\subsection{K-Nearest Neighbor $(K N N)$}

KNN adalah salah satu dari beberapa metode klasifikasi dengan pembelajaran disupervisi dalam ranah Kecerdasan Artifisial (Artificial Intelligence). Pembelajaran dilakukan dengan melakukam penempatan data-data pada kelas-kelas yang bersesuaian berdasarkan pada jarak paling dekat dengan objek tersebut. Detil dari Langkah-langkah dalam algoritma KNN dapat dilihat pada (Andono, Sutojo, \& Muljono, 2017). Mekanisme utama algoritma KNN adalah pembandingan jarak antara dua titik yakni data latih $(x)$ dan data uji $(y)$, menggunakan formula jarak Euclidean sebagaimana diperlihatkan pada Persamaan (12) (Siregar \& Puspabhuana, 2017),

$$
D(x, y)=\sqrt{\sum_{k=1}^{n}\left(x_{k}-y_{k}\right)^{2}}
$$

Dalam penelitian ini nilai $\mathrm{K}$ menggunakan angka ganjil seperti $K=1,3,5,7,9,11,13,15,17,19$ guna memperoleh akurasi klasifikasi yang tinggi (Ana, Gede, \& Irfan, 2017) (Rizal, 2019). Dalam buku yang berjudul Clinical Research Computing menyebutkan nilai $K$ adalah akar kuadrat dari sebanyak jumlah data pelatihan, $N$. Maka, jika $N$ adalah 400, maka $K=20$ (Nadkarni, 2016). Bila $K=20$, maka pada umumnya akan diambil nilai ganjil yakni $K=19$ atau $K=21$.

\section{IMPLEMENTASI SISTEM KLASIFIKASI TELUR BURUNG PUYUH DAN PENGUJIAN KINERJANYA}

\subsection{Implementasi Sistem}

Sistem klasifikasi berbasis KNN dan fusi informasi ini diimplementasikan dengan bahasa pemrograman $\mathrm{C \#}$ menjadi sebuah aplikasi yang dapat dijalankan pada komputer desktop atau laptop. Dengan merujuk pada Gambar 3, secara umum proses pertama yaitu memasukkan citra telur burung Puyuh ke sistem. Selanjutnya pada tahap preprocessing, citra telur burung Puyuh tersebut akan dipotong sesuai kebutuhan (cropping) dan diubah ukurannga (resize) menjadi ukuran 256 x 256.

Proses selanjutnya adalah ekstraksi fitur warna dengan mengambil nilai RGB kemudian dilakukan normalisasi RGB dan disimpan nilainya. Untuk ekstraksi fitur tekstur citra telur burung Puyuh diubah terlebih dulu ke citra skala keabuan (grayscale) dan selanjutnya Otsu thresholding akan menghitung jumlah pixel hitam dan pixel puth setelah itu disimpan. Setelah mendapatkan hasil ekstraksi fitur warna dan tekstur kemudian dilakukan proses fusi informasi yang selanjutnya di dapatkan nilai fusi. Pada proses klasifikasi disini menggunakan metode KNN dan menggunakan nilai fusi sebagai nilai masukan. Setelah dilakukan proses klasifikasi maka di dapatkan hasil kelas klasifikasi telur burung Puyuh.

\subsection{Pelatihan Sistem}

Tahapan-tahapan pelatihan sistem diperlihatkan pada Gambar 4 sampai dengan Gambar 7 yang mana memperlihatkan pengolahan awal data citra burung Puyuh, dan dilanjutkan dengan pelatihan sistem. Data awal berupa telur dengan mutu Baik, Sedang, dan Buruk sebagai masukan ke sistem diletakkan pada kolom kiri atas lengkap dengan nama file yang menunjukkan klasifikasinya berdasarkan hasil observasi pekerja peternakan. Contoh pada Gambar 4, diperlihatkan bahwa data citra yang diolah adalah citra dari telur burung Puyuh kualitas Baik dengan nama file Baik_3.jpg.

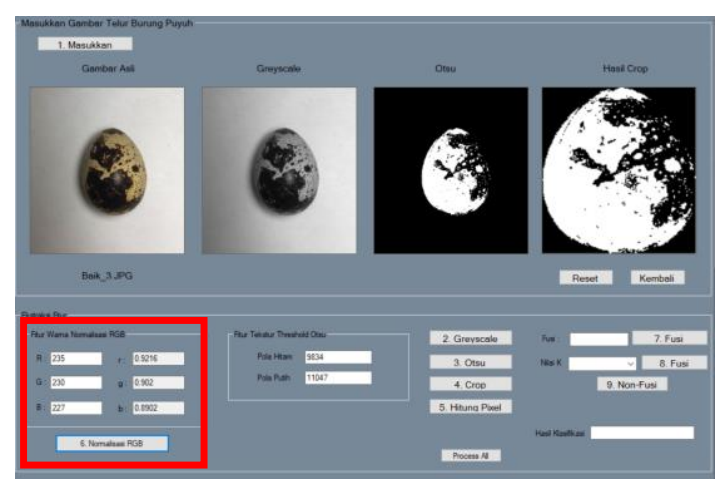

Gambar 4. Ekstraksi fitur warna menggunakan normalisasi RGB.

Preprocessing dilakukan dengan mengubah warna citra ke skala keabuan sebelum dilakukan proses berikutnya yakni ekstraksi fitur warna dan fitur tekstur. Ekstraksi fitur warna dilakukan menggunakan metode normalisasi RGB (Subbagian 2.2) yang diperlihatkan pada Gambar 4, sedangkan ekstraksi fitur tekstur dilakukan menggunakan metode Otsu thresholding (Subbagian 2.3) yang diperlihatkan pada Gambar 5. Kedua fitur hasil ekstraksi akan difusikan terlebih dulu untuk memperoleh satu fitur yang akan menjadi masukan bagi pengklasifikasi KNN menggunakan metode fusi informasi dengan operator AND (Subbagian 2.4) sebagaimana diperlihatkan pada Gambar 6. 


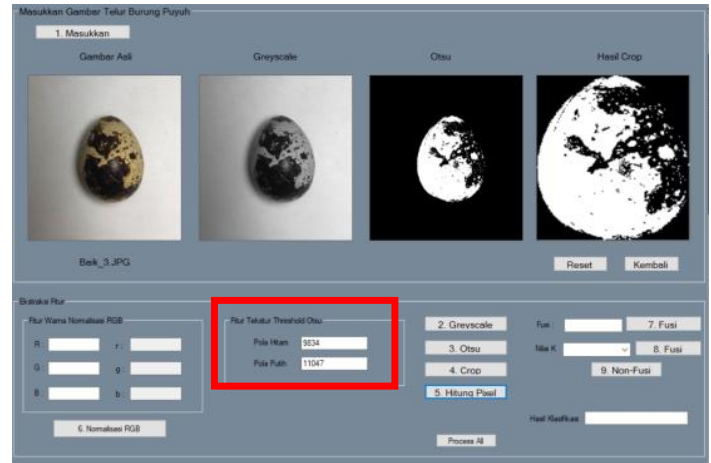

Gambar 5. Ekstraksi fitur tekstur menggunakan metode Otsu.

Setelah melalui proses pelatihan dengan referensi mutu Baik, hasil pelatihan akan disimpan ke dalam basis pengetahuan. Proses pelatihan ini dilakukan pada 270 data citra telur burung Puyuh dengan 3 macam kategori mutu yakni Baik, Sedang, dan Buruk. Mekanisme pelatihan sistem klasifikasi telur burung Puyuh diperlihatkan pada Gambar 7 .

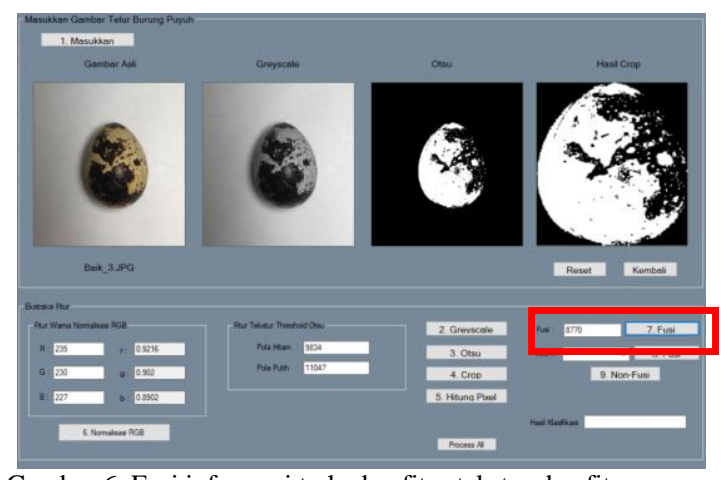

Gambar 6. Fusi informasi terhadap fitur tekstur dan fitur warna.

\subsection{Pengujian Sistem}

Kinerja sistem diuji dengan 30 data citra telur burung Puyuh yang belum pernah dilatihkan atau diperlihatkan ke sistem sama sekali. Pengujian dilakukan dengan menggunakan nilai $K$ mengikuti konsep dari (Nadkarni, 2016) yakni $K=\sqrt{N}=$ $\sqrt{270}=16,43$. Untuk objektivitas pengujian, maka digunakan $\mathrm{K}$ ganjil di 16,43 yakni 1 sampai sampai dengan 9 dan 15 , dan satu $K$ ganjil diatas 16,43 yakni 17. Mekanisme pengujian diperlihatkan pada Gambar 8. Sebagai benchmark, akurasi rata-rata yang dicapai sistem dengan menggunakan fitur terfusi dan fitur tidak terfusi diperlihatkan pada Tabel 2 dan Tabel 3.

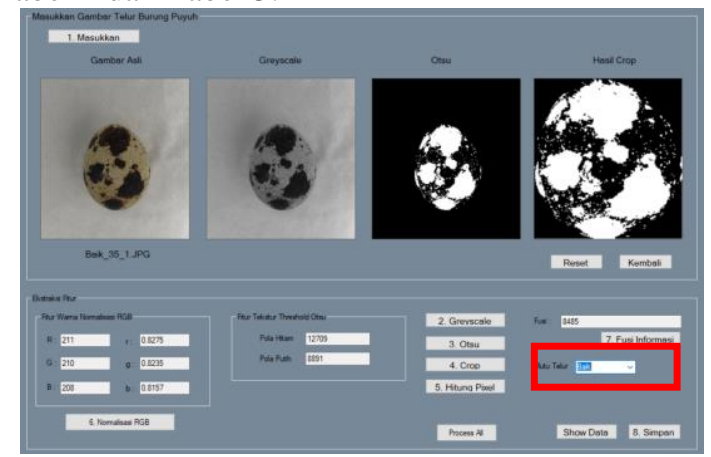

Gambar 7. Pelatihan sistem dan pelabelan data citra menggunakan 270 data citra telur burung Puyuh.

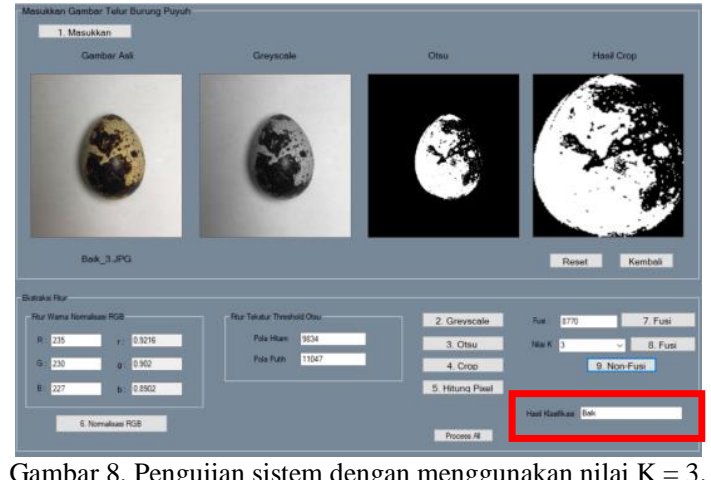

Gambar 8. Pengujian sistem dengan menggunakan nilai $\mathrm{K}=3$.

Tabel 2. Akurasi rata-rata pengujian sistem menggunakan fitur terfusi (fusi informasi)

\begin{tabular}{ccc}
\hline No & $\mathrm{K}$ & Akuisisi Rata-rata \\
\hline 1 & $\mathrm{~K}=1$ & $66,67 \%$ \\
2 & $\mathrm{~K}=3$ & $71,11 \%$ \\
3 & $\mathrm{~K}=5$ & $71,11 \%$ \\
4 & $\mathrm{~K}=7$ & $77,78 \%$ \\
5 & $\mathrm{~K}=9$ & $75,56 \%$ \\
6 & $\mathrm{~K}=15$ & $73,33 \%$ \\
7 & $\mathrm{~K}=17$ & $68,89 \%$ \\
\hline
\end{tabular}

Tabel 3. Akurasi rata-rata pengujian sistem tanpa menggunakan

\begin{tabular}{ccc} 
& \multicolumn{2}{c}{ fusi fitur (fusi informasi) } \\
\hline No & $\mathrm{K}$ & Akuisisi Rata-rata \\
\hline 1 & $\mathrm{~K}=1$ & $63,33 \%$ \\
2 & $\mathrm{~K}=3$ & $62,22 \%$ \\
3 & $\mathrm{~K}=5$ & $66,67 \%$ \\
4 & $\mathrm{~K}=7$ & $66,67 \%$ \\
5 & $\mathrm{~K}=9$ & $73,33 \%$ \\
6 & $\mathrm{~K}=15$ & $64,44 \%$ \\
7 & $\mathrm{~K}=17$ & $64,44 \%$ \\
\hline
\end{tabular}

Dari kedua tabel tersebut dapat dilihat bahwa akurasi rata-rata dari hasil klasifikasi menggunakan fitur terfusi mengungguli akurasi rata-rata dari hasil klasifikasi yang tidak menggunakan fitur terfusi bahkan pada nilai $K$ yang sama. Nilai akurasi tertinggi hasil klasifikasi menggunakan fitur terfusi dicapai pada nilai $K=7$ sebesar sebesar 77,78\%. Di sisi lain, nilai akurasi terbesar dari klasifikasi tanpa fusi informasi dicapai pada $K=9$ sebesar $73,33 \%$. Nilai akurasi ini masih dibawah nilai akurasi dengan fusi informasi pada nilai $K$ yang sama yakni $75,56 \%$. Pada Tabel 4 dan Tabel 5 diperlihatkan cara memperoleh akurasi per kategori telur burung Puyuh bermutu Baik, Sedang, dan Buruk, serta akurasi ratarata masing-masing baik menggunakan fitur terfusi (fusi informasi) maupun tanpa fusi fitur.

Tabel 4. Cofusion matrix dari pengujian sistem menggunakan fitur terfusi (fusi informasi) pada nilai $K=\mathbf{7}$

\begin{tabular}{ccccc}
\hline $\mathbf{N}=\mathbf{3 0}$ & & \multicolumn{3}{c}{ Prediksi } \\
\hline & & Baik & Sedang & Buruk \\
\hline & Baik & 5 & 3 & 2 \\
\hline Aktual & Sedang & 2 & 6 & 2 \\
\hline & Buruk & 1 & 0 & 9 \\
\hline
\end{tabular}

Berdasarkan pada Tabel 4, untuk kategori Baik diperoleh nilai $T P=5, T N=(6+2+0+9)=17$, $F P=(3+2)=5$, dan $F N=(2+1)=3$. Selanjutnya 
untuk kategori Sedang diperoleh $T P=6, \quad T N=$ $(5+2+1+9)=17, \quad F P=(2+2)=4, \quad$ dan $\quad F N=$ $(3+0)=3$, dan untuk kategori Buruk diperoleh $T P=9$, $T N=(5+3+2+6)=16, \quad F P=(1+0)=1, \quad$ dan $F N=(2+2)=4$. Maka akurasi sistem dengan fitur terfusi untuk per kategori pada $K=7$ adalah sebagai berikut:

$$
\begin{aligned}
\text { Akurasi }_{\text {Baik }}= & \frac{T P+T N}{T P+T N+F P+F N} \times 100 \% \\
= & \frac{5+17}{5+17+5+3} \times 100 \% \\
= & \frac{22}{30} \times 100 \% \\
& =73,33 \% \\
\text { Akurasi }_{\text {Sedang }} & =\frac{T P+T N}{T P+T N+F P+F N} \times 100 \% \\
& =\frac{6+17}{6+17+4+3} \times 100 \% \\
& =\frac{23}{30} \times 100 \% \\
& =76,67 \% \\
\text { Akurasi }_{\text {Buruk }} & =\frac{T P+T N}{T P+T N+F P+F N} \times 100 \% \\
& =\frac{9+16}{9+16+1+4} \times 100 \% \\
& =\frac{25}{30} \times 100 \% \\
& =83,33 \% \\
& =\left(\frac{73,33+76,67+83,33}{3}\right) \% \\
& =77,78 \% \\
\text { Akurasi }_{\text {rata-rata }} & =\left(\frac{\text { Akurasi }}{\{\text { Baik,Sedang,Buruk\} }}\right) \% \\
3 &
\end{aligned}
$$

Tabel 5. Akurasi pengujian sistem tanpa menggunakan fusi fitur (fusi informasi) pada nilai $\boldsymbol{K}=\mathbf{7}$

\begin{tabular}{ccccc}
\hline $\mathbf{N = 3 0}$ & & \multicolumn{3}{c}{ Prediksi } \\
\hline & & Baik & Sedang & Buruk \\
\hline Bktual & Sedang & 1 & 6 & 4 \\
\hline & Buruk & 1 & 5 & 4 \\
\hline
\end{tabular}

Berdasarkan pada Tabel 5, untuk kategori Baik diperoleh nilai $T P=5, T N=(6+3+5+4)=18$ $F P=(1+4)=5$, dan $F N=(1+1)=2$. Selanjutnya untuk kategori Sedang diperoleh $T P=6, \quad T N=$ $(1+4+5+4)=14, \quad F P=(1+3)=4, \quad$ dan $F N=$ $(1+5)=6$, dan untuk kategori Buruk diperoleh $T P=4$, $T N=(5+1+1+6)=13, \quad F P=(1+5)=6, \quad$ dan $F N=(3+4)=7$. Maka akurasi sistem tanpa fusi fitur untuk per kategori pada $K=7$ adalah sebagai berikut:

$$
\begin{aligned}
\text { Akurasi }_{\text {Baik }} & =\frac{T P+T N}{T P+T N+F P+F N} \times 100 \% \\
& =\frac{5+18}{5+18+5+2} \times 100 \% \\
& =\frac{23}{30} \times 100 \% \\
& =76,67 \% \\
\text { Akurasi }_{\text {Sedang }} & =\frac{T P+T N}{T P+T N+F P+F N} \times 100 \% \\
& =\frac{6+14}{6+14+4+6} \times 100 \%
\end{aligned}
$$

$$
\begin{aligned}
& =\frac{20}{30} \times 100 \% \\
& =66,67 \%
\end{aligned}
$$

$$
\begin{aligned}
\text { Akurasi }_{\text {Buruk }} & =\frac{T P+T N}{T P+T N+F P+F N} \times 100 \% \\
& =\frac{4+13}{4+13+6+7} \times 100 \% \\
& =\frac{17}{30} \times 100 \% \\
& =56,67 \%
\end{aligned}
$$

$$
\begin{aligned}
\text { Akurasi }_{\text {rata-rata }} & =\left(\frac{\text { Akurasi }_{\{\text {Baik,Sedang,Buruk }\}}}{3}\right) \% \\
& =\left(\frac{76,67+66,67+56,67}{3}\right) \% \\
& =66,67 \%
\end{aligned}
$$

\subsection{Analisa dan Pembahasan}

Pengujian sistem dilakukan dengan cara membandingkan kinerja pengklasifikasi KNN ketika diberikan masukan berupa fitur terfusi dan tanpa fusi fitur atau tanpa fusi informasi. Berdasarkan pada hasil-hasil pengujian yang telah disampaikan, walau dengan nilai $K$ yang sama, klasifikasi dengan masukan dengan fitur terfusi mampu mengungguli klasifikasi dengan fitur tak terfusi atau tanpa fusi fitur. Maka, sistem klasifikasi dengan fusi informasi mengungguli sistem klasifikasi tanpa menggunakan fusi informasi.

Pengujian kedua adalah membandingkan kecepatan klasifikasi dengan menggunakan fusi informasi dengan yang tidak menggunakan fusi informasi. Dari penelitian diperoleh hasil bahwa komputasi sistem klasifikasi menggunakan fusi informasi lebih cepat 0,22 detik daripada sistem klasifikasi tanpa fusi informasi. Hal ini dimungkinkan karena pengklasifikasi KNN hanya mengolah satu nilai yakni fitur terfusi, sedangkan yang tanpa fitur terfusi harus mengolah dua nilai fitur secara bersamaan yang secara otomatis akan menambah waktu komputasi.

Secara teori, nilai $K$ kecil dapat berdampak pada sensitif terhadap derau (noise) sedangkan bila nilai $K$ terlalu besar dapat berdampak masuknya data dari kelas lain (Gunawardena, 2016). Nilai $K$ umumnya adalah $\sqrt{N}$ dan dari penelitian diperoleh hasil nilai $K$ dengan akurasi tertinggi adalah 7. Nilai ini dapat dianggap sebagai nilai $K$ yang representatif yakni meminimalkan derau dan mencegah tercakupnya data dari kelas lain sehingga hasil klasifikasi yang diperoleh adalah valid.

\section{KESIMPULAN DAN SARAN}

\subsection{Kesimpulan}

Berdasarkan dari hasil-hasil penelitian serta analisa dan pembahasan dapat disimpulkan bahwa:

- Sistem klasifikasi telur burung Puyuh menggunakan KNN dan fusi informasi 
mampu melakukan klasifikasi terhadap tiga macam mutu telur burung tak yakni Baik, Sedang, dan Buruk dengan akurasi sebesar $77,78 \%$ pada nilai $K=7$.

- Fusi informasi telah berhasil meningkatkan akurasi prediksi pengklasifikasi KNN dengan selisih akurasi sebesar $11,11 \%$ pada nilai $K=7$ terhadap klasifikasi tanpa fusi informasi.

- Fusi informasi mampu mempercepat klasifikasi dengan selisih waktu 0,22 detik dibandingkan dengan yang tanpa fusi informasi. Selisih waktu ini sangat signifikan ketika jumlah data yang diproses sangat banyak.

\subsection{Saran}

Untuk pengembangan lebih lanjut sistem klasifikasi ini dapat dikembangkan dengan menggunakan metode fusi informasi yang lebih baik guna memperoleh akurasi yang lebih tinggi. Di samping itu, guna fleksibilitas dalam penggunaannya di lapangan, sistem klasifikasi ini dapat dikembangkan ke sistem berbasis android. Kemudian untuk aspek pelatihan dan pengujian sistem akan dibandingkan dengan metode cross validation atau lebih sering dikenal dengan $k$-fold cross validation.

\section{DAFTAR PUSTAKA}

ABADI, S., HUDA, M., JASMI, K.A., SHAKIB, S., NOOR, M., SAFAR, J., MOHAMED, A.K., EMBONG, W.H.W., MOHAMAD, A.M., HEHSAN, A., BASIRON, B., IHWANI, S.S., MASELENO, A., MUSLIHUDIN, M., SATRIA, F., IRAWAN, D., \& HARTATI, S., 2018. Determination of the best quail eggs using simple additive weighting. International Journal of Engineering \& Technology, 7(2.27). pp. 225-230.

ANA T.N., GEDE, P.S.W., \& IRFAN, L.A.S. 2017. Klasifikasi Warna Kulit Manusia Dengan Algoritma K-Nearest Neighbor. Jurnal Dielektrika, 4(2), pp. 137-140,

ANDONO, P.N., SUTOJO, T., \& MULJONO., 2017. Pengolahan Citra Digital. Edisi 1, Yogyakarta: Andi.

ASMARA, R.A., 2018. Pengolahan Citra Digital: Pengolahan Citra Digital, Edisi 1, Malang: Polinema Press.

GUNAWARDENA, T., 2016. Algorithms: K Nearest Neighbors, https://www.slideshare.net/tilanigunawarde na/k-nearest-neighbors.

HAN, J., KAMBER, M., \& PEI, J., 2012. Data Mining Concepts \& Techniques Third Edition, 365-367, San Fransisco: Elsevier.
KUSMANTO, R.D., \& TOMPUNU, A.N., 2011. Pengolahan Citra Digital Untuk Mendeteksi Obyek Menggunkan Pengolahan Warna Model Normalisasi RGB. Seminar Nasional Teknologi Informasi \& Komunikasi Terapan 2011 (Semantik 2011), [online]. Tersedia di: http://publikasi.dinus.ac.id/index.php/sema ntik/article/view/153/116> [Diakses $30 \mathrm{Mei}$ 2011].

MAHARDIKA, A.A., SAPTONO, R., \& ANGGRAININGSIH, R., 2015. Sistem Klasifikasi Feedback Pelanggan Dan Rekomendasi Solusi Atas Keluhan Di Upt Puskom Uns dengan Algoritma Nä̈ve Bayes Classifier dan Cosine Similarity. Jurnal ITSMART, 4(1), pp. 39-40.

NADKARNI, P., 2016. Core Technologies: Data Mining and Big Data. Clinical Research Computing, 187-204 [online]. Tersedia di: $<$ https://doi.org/10.1016/b978-0-12803130-8.00010-5> [Diakses 20 Mei 2020].

NINGRUM, N.K., HENDRIYANTO, N., \& KURNIAWAN, D., 2017. Pengaruh Thresholding Otsu Pada Klasifikasi Motif Batik Pesisir Menggunakan K-Nearest Neighbour. Prosiding Science and Engineering National Seminar 3 (SENS 3), pp. 142-147.

OTSU, N., 1979, A Threshold Selection Method from Gray-Level Histogram. IEEE Transactions on Systems, Man, and Cybernetics, SMC-9(1), pp. 62-66.

RAHMADIANTO, R., MULYANTO, E., \& SUTOJO, T., 2019. Implementasi Pengolahan Citra dan Klasifikasi K-Nearest Neighbor untuk Mendeteksi Kualitas Telur Ayam. Jurnal Voice of Informatics, 8(1), pp. $45-54$.

RIZAL, M.A., 2019. Tesis Tugas Akhir: Klasifikasi Mutu Biji Kopi Menggunakan Metode $K$ Nearest Neighbor Berdasarkan Warna dan Tekstur. Jurnal Informatika, [online]. Tersedia di: < http://eprints.uty.ac.id/2675/> [Diakses 8 Juni 2020].

SAPARINTO, C., \& MARSUDI., 2012. Puyuh. Edisi Pertama Penebar Swadaya. 6. Jakarta.

SIREGAR, A.M., \& PUSPABHUANA, A., 2017. Data Mining: Pengolahan Informasi Data dengan Rapid Miner, Surakarta: Kekata Publisher.

SU, S.Z., \& CHEN, S.Y., 2013. Analysis of feature fusion based on HIK SVM and its application for pedestrian detection, [online]. Tersedia di: < 
https://www.hindawi.com/journals/aaa/201

3/436062/> [Diakses 4 April 2020].

SULTONI, M.I., HIDAYAT, B., \& SUBANDRIO,

A. S., 2019. Klasifikasi Jenis Batuan Beku Melalui Citra Berwarna Dengan Menggunakan Metode Local Binary Pattern dan K-Nearest Neighbor. Jurnal Tektrika, 4(1), pp. 10-15,

SUMARI, A.D.W., \& AHMAD, A.S., 2008. Designing MultiAgent-based Information Fusion System. The $1^{\text {st }}$ Makassar International Conference on Electrical Engineering and Informatics 2008, pp. 137143.

SUMARI, A.D.W., \& AHMAD, A.S., 2016. The Fusion of Artificial Intelligence and Information Fusion. International Symposium on Electronics and Smart Devices 2016, [online]. Tersedia di: < https://ieeexplore.ieee.org/document/78867 54> [Diakses 21 Mei 2020].

SUMARI, A. D. W., \& AHMAD, A. S., 2017. Information Fusion as Knowledge Extraction in an Information Processing System. International Journal of Artificial Intelligence and Neural Networks, 7(1), pp. 22-27.

SYAFI'I, S.I., WAHYUNINGRUM, R.T., \& MUNTASA, A., 2015. Segmentasi Obyek Pada Citra Digital Menggunakan Metode Otsu Thresholding. Jurnal Informatika, 13(1), pp. 1-8.

WIDYARDINI, S.T., 2015. Pemrograman Matlab untuk Pengolahan CItra Digital: Studi Kasus Sistem Pemantau Ruangan Pengganti CCTV, Edisi 1, 24, Malang: Universitas Brawijaya Press.

WURYADI, S., 2013. Beternak Puyuh. Edisi 1. Jakarta: PT AgroMedia Pustaka. 
Halaman ini sengaja dikosongkan 